\title{
良聴耳聴力レベル 90dBHL 未満の症例に対する 人工内耳の術後語音聴取能の検討
}

\author{
勝然昌子 ${ }^{1)}$, 尾形エリカ ${ }^{2)}$, 赤松裕 ${ }^{2)}$, 樫尾明憲 ${ }^{2)}$, 狩野章太郎 ${ }^{2)}$, 岩㟝真一 ${ }^{2)}$, 山岨達也 ${ }^{2)}$ \\ ${ }^{1)}$ NTT 東日本関東病院耳鼻咽喉科・頭頸部外科 \\ ${ }^{2)}$ 東京大学医学部附属病院耳鼻咽喉科・頭頸部外科
}

\begin{abstract}
要旨: 本邦の成人人工内耳の適応基準は聴カレベルに重点を置いているが, 米国などの諸 外国では語音聴取能に重点を置いたものも存在する。本邦でも聴力レベルが保たれていて も語音聴取能が悪く, 実用的な音声コミュニケーションが困難な症例が存在する。今回 我々は，良聴耳聴力レベルが 4 分法で $90 \mathrm{dBHL}$ 未満であるが語音聴取能が不良なため, 当科で人工内耳手術を行った中途失聴成人 9 症例の術後成績を検討した。全 9 症例の術後 語音聴取能の平均は, 両側術前聴力レベルが 90dBHL 以上症例の術後語音聴取能の平均 とほほ同等であった。術側耳の聴力レベルが 90dBHL 未満であった症例は 4 例で全例良 好な術後成績が得られた，術側耳の聴力レベルが 90dBHL 以上で非術側耳の聴力レベル が 90dBHL未満であった 5 症例では術後成績にばらつきを認めた。本研究から語音聴取 能が不良な聴力レベルが 90dBHL 未満の症例にも人工内耳の良い適応となる症例が存在 することが示唆された。
\end{abstract}

$$
\text { ーキーワードー }
$$

人工内耳, 適応基準, 聴カレベル, 語音聴取能

\section{はじめに}

成人に対する人工内耳の適応基準（2006）は，本 邦では「純音聴力は原則として両耳とも $90 \mathrm{dBHL}$ 以上の重度難聴者で, かつ補聴器の装用効果の少な いもの」と聴力レベルに重点を置いたものとなって いるが, 各国でその適応規準は異なる。Cochlear 社のホームページ http://www.cochlear.com/wps/ $\mathrm{wcm} /$ connect/us/for-professionals/products/cochlear-implants/candidacy（2017年 1 月 4 日）に記載 されている米国における成人人工内耳の適応基準は 「Moderate to profound sensorineural hearing loss in both ears. Limited benefit from amplification defined by preoperative test scores of $\leqq 50 \%$ sentence recognition in the ear to be implanted and $\leqq 60 \%$ in the opposite ear or binaurally」であり, 語音聴取能
に重点を置いたものとなっている。米国のみでな く, ドイツやフランス，スイスなどでも成人の人工 内耳適応基準に語音聴取能を採用しており, 聴力レ ベルに関しては基準が無い，または適応の幅が広く 設定されている12) $($ 表 1)。また, Deborah らの報 告 ${ }^{3)}$ でも, 調查した $85 \%$ の国で成人の人工内耳の適 応基準において語音聴取能を採用しているとされて いる。良聴耳の聴力レベルが 90dBHL未満であっ た症例への人工内耳埋込み術の術後成績について は, 両側とも 90dBHL 以上であった症例と比較し て術後成績が良好であったという海外の報告(4) が ある。

本邦においても, 聴力レベルが 90dBHL未満で あっても語音聴取能不良例が存在することは既に報 告されており ${ }^{6)}$, 聴力レベルが保たれていても実用 的な音声コミュニケーションが困難な症例を時に経 
表 1 各国の人工内耳適応基準（参考文献 $1 ， 2$ より一部改訂）

\begin{tabular}{|c|c|c|c|}
\hline & \multicolumn{2}{|l|}{ 裸耳聴力 } & 補聴器装用下語音聴取能 \\
\hline アメリカ & 中等度・重度 & 高度難聴 & $\begin{aligned} \text { 文章 } & \leqq 50 \% \text { （術側） } \\
& \leqq 60 \% \text { (両耳， 非術側) }\end{aligned}$ \\
\hline ドイツ & $250 \mathrm{~Hz}-8 \mathrm{kHz}$ & $\geqq 70 \mathrm{dBHL}$ & 単音節＜50\% \\
\hline フランス & きまりなし & & 2 音節 $<50 \%$ \\
\hline イギリス & $2 \mathrm{kHz}-4 \mathrm{kHz}$ & $\geqq 90 \mathrm{dBHL}$ & 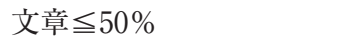 \\
\hline スイス & きまりなし & & 単音節＜40\% \\
\hline オーストラリア & 中等度·重度 & 高度難聴 & 単音節＜60\% \\
\hline 韓国 ～～～～～～～～ & $250 \mathrm{~Hz}-8 \mathrm{kHz}$ & $\geqq 90 \mathrm{dBHL}$ & 文章＜50\% \\
\hline 日本 & 重度難聴 & $\geqq 90 \mathrm{dBHL}$ & 規定なし \\
\hline
\end{tabular}

験する。以上の背景から，当科で過去に人工内耳を 施行した症例のなかで，良聴耳聴力レベルが 90 dBHL 未満であったものの語音聴取能不良のため手 術が検討された症例において，その経緯・術後成績 を検討し，人工内耳適応基準について考察を加えて 報告する。

\section{対象と方法}

東京大学医学部附属病院で2005年から2015年に人 工内耳埋め达み術を施行した成人中途失聴症例 61 症 例から，良聴耳平均聴力レベルが 4 分法で 90dBHL 未満であった 9 症例（男性 8 例，女性 1 例：年齢 20-74歳，平均年齢52歳）を抽出した。当科では聴 カレベルが $90 \mathrm{~dB}$ 未満であっても補聴器装用下の聴 取能が $50 \%$ 未満の場合, 本邦の人工内耳埋込み術の 適応基準外であることを患者に伝え，かつ科内で十 分に検討したうえで，患者の強い希望があった場合 には人工内耳埋込み術を行うこととしている。術側 耳の聴力レベルが 90dBHL 未満であった症例群（以 下術側 90dBHL未満群) が 4 例, 術側耳の聴力レ ベルが 90dBHL 以上で非術側耳の聴力レベルが 90 dBHL 未満であった症例（以下非術側 90dBHL未満 群）が5例であった。使用した人工内耳機種は全例 コクレア社製であり，全例で内耳奇形は認めなかっ た。各症例の背景を表 2,3 に, 術前のオージオグ ラムを図 1 に示す。聴力レベルは全て 4 分法で記載 している。

聴力の評価は標準純音聴力検査のほかに，聴性脳 幹反応（以下 $\mathrm{ABR}$ ) を用いて実施した。ABRは 0.1 ミリ秒幅のクリック音を用い, 刺激頻度は $10 \mathrm{~Hz}$, 解析時間は $20 ミ リ$ 秒, 加算回数は 1000 回とした。最
大 $105 \mathrm{~dB}$ まで測定している。

術前の術側裸耳語音聴取能は 67-S 語表単音節検 査（日本聴覚医学会）を用いて測定した。またその 他に, ビデオを用いた福田版明瞭度検査（福田 1989）の単音節語表を用いて術前・術後の語音聴取 能の評価を行った。評価は防音室内において, 術前 評価は補聴器装用下に, 術後評価は人工内耳のみを 装用する条件で実施した。音声と映像は対象者の正 面 $1 \mathrm{~m}$ から提示されるが，本研究における術前・術 後の聴取能の比較は音声のみを提示する条件の評価 を用いて行い, 術後聴取能は最も成績が良好であっ た時期のものを採用した。

\section{結果}

全 9 症例の術前語音聴取能は平均 $16.8 \%$, 術後語 音聴取能は平均 $58.4 \%$ であった。続いて, 術側に聴 カレベルが 90dBHL未満の耳を選択した群と, 90 dBHL 未満の耳を温存し 90dBHL 以上の悪聴耳に人 工内耳埋込み術を行った群に分け検討を行った。

1 ) 術側 90dBHL未満群（表 2)

術前語音聴取能は平均 $18.5 \%$, 術後語音聴取能は 平均 $82 \%$ であった。症例 $\mathrm{A}$ は非術側に聴神経腫瘍が 存在し, 聴力レベルは90dBHL 以上であった。症 例 $\mathrm{B}$ は䯣膜炎後の蝸牛骨化を非術側に認め, この耳 の聴力レベルは90dBHL 以上であった。術側でも 蝸牛の骨化が進行することを危惧し，90dBHL未満 の耳に対して人工内耳埋込み術を行った。症例 C と 症例Dは両側ともに聴力レベルが 90dBHL未満で あった。症例 $\mathrm{D} は, 15$ 年前の突発性難聴により術側 聴力は低下していた。当時の聴力レベルや難聴の進 行の有無は不明であるが, 補聴器は使用していなか 
表 2 術側 90dBHL 未満群（聴力は 4 分法で表示）

術前の術側裸耳語音聴取能は 67-S 語表単音節検査（日本聴覚医学会）を用いて測定し, 術前・術後の聴 取能は福田版明瞭度検查（福田1989）の単音節語表を用い術前評価は補聴器装用下に, 術後評価は人工 内耳のみを装用する条件で実施した。

\begin{tabular}{|c|c|c|c|c|c|c|c|c|c|c|c|c|}
\hline \multirow{2}{*}{ 症例 } & \multirow{2}{*}{ 年齢 } & \multirow{2}{*}{ 性別 } & \multirow{2}{*}{ 失聴原因 } & \multirow{2}{*}{ 術側 } & \multirow{2}{*}{$\begin{array}{c}\text { 術側 } \\
\text { 失聴期間 }\end{array}$} & \multirow{2}{*}{$\begin{array}{c}\text { 術前聴力 } \\
\text { 術側 }\end{array}$} & \multirow{2}{*}{$\begin{array}{l}\text { (dBHL) } \\
\text { 非術側 }\end{array}$} & \multirow{2}{*}{$\begin{array}{l}\text { 補聴器 } \\
\text { 装用耳 }\end{array}$} & \multirow{2}{*}{ 機種 } & \multicolumn{3}{|c|}{ 聴取能（\%） } \\
\hline & & & & & & & & & & 裸耳 & 術前 & 術後 \\
\hline A & 59 & M & 原因不明 & 左 & 6 年 & 81 & 134 & 術側 & $\begin{array}{c}\text { CI24RE } \\
\text { (CA) }\end{array}$ & 20 & 22 & 72 \\
\hline B & 41 & M & 髄膜炎 & 左 & 10ヶ月 & 88 & 90 & 両側 & $\begin{array}{l}\mathrm{CI} 24 \mathrm{R} \\
(\mathrm{CS})\end{array}$ & 5 & 18 & 84 \\
\hline $\mathrm{C}$ & 52 & M & 原因不明 & 左 & 1 年 & 86 & 81 & 両側 & $\begin{array}{c}\text { CI24RE } \\
(\mathrm{CA})\end{array}$ & 40 & 22 & 88 \\
\hline $\mathrm{D}$ & 52 & M & $\begin{array}{c}\text { 突発性 } \\
\text { 難聴 }\end{array}$ & 左 & 1 年 9 ケ月 & 86 & 84 & 非術側 & $\begin{array}{c}\text { CI24RE } \\
(\mathrm{CA})\end{array}$ & 35 & 12 & 84 \\
\hline
\end{tabular}

表 3 非術側 90dBHL 未満群（聴力は 4 分法で表示）

術前の術側裸耳語音聴取能は $67-\mathrm{S}$ 語表単音節検査（日本聴覚医学会）を用いて測定し, 術前・術後の聴 取能は福田版明膫度検査（福田1989）の単音節語表を用い術前評価は補聴器装用下に, 術後評価は人工 内耳のみを装用する条件で実施した。

\begin{tabular}{|c|c|c|c|c|c|c|c|c|c|c|c|c|}
\hline \multirow{2}{*}{ 症例 } & \multirow{2}{*}{ 年齢 } & \multirow{2}{*}{ 性別 } & \multirow{2}{*}{ 失聴原因 } & \multirow{2}{*}{ 術側 } & \multirow{2}{*}{$\begin{array}{c}\text { 術側 } \\
\text { 失聴期間 }\end{array}$} & \multirow{2}{*}{$\begin{array}{c}\text { 術前聴力 } \\
\text { 術側 }\end{array}$} & \multirow{2}{*}{$\begin{array}{l}\text { (dBHL) } \\
\text { 非術側 }\end{array}$} & \multirow{2}{*}{$\begin{array}{l}\text { 補聴器 } \\
\text { 装用耳 }\end{array}$} & \multirow{2}{*}{ 機種 } & \multicolumn{3}{|c|}{ 聴取能（\%） } \\
\hline & & & & & & & & & & 裸耳 & 術前 & 術後 \\
\hline $\mathrm{E}$ & 47 & M & 髄膜炎 & 左 & 4 年 & 134 & 69 & 非術側 & $\begin{array}{c}\text { CI24RE } \\
(\mathrm{CA})\end{array}$ & 0 & 0 & 2 \\
\hline $\mathrm{F}$ & 74 & $\mathrm{~F}$ & 髄膜炎 & 右 & 1 年 4 ケ月 & 134 & 79 & 両耳 & CI24RST & 0 & 0 & 26 \\
\hline G & 20 & M & 原因不明 & 右 & 11年 & 134 & 76 & 両耳 & CI24M & - & - & 4 \\
\hline $\mathrm{H}$ & 65 & M & 原因不明 & 左 & 4 年 & 100 & 80 & 非術側 & $\begin{array}{c}\text { CI24RE } \\
(\mathrm{CA})\end{array}$ & 0 & 44 & 80 \\
\hline I & 62 & M & $\begin{array}{c}\text { 慢性 } \\
\text { 中耳炎 }\end{array}$ & 左 & 1 年 & 129 & 86 & 両耳 & CI24M & - & 16 & 86 \\
\hline
\end{tabular}

った。 1 年 9 カ月前に良聴耳であった非術側の聴力 が低下し始め, その時の術側の聴力レベルは 86 $\mathrm{dBHL}$ ，裸耳語音聴取能は $67-\mathrm{S}$ 語表単音節検查（日 本聴覚医学会) で35\%であった。補聴器装用を開始 したが，術側は長期に渡り補聴器を使用しておらず 非術側のみ補聴器を常用していたことから，術前語 音聴取能は非術側補聴器装用下で評価した。症例 A ・ C ・ D は経過観察中に徐々に聴力の低下を認め て語音聴取能が悪化した症例であり, 補聴器の装用 効果がそしいと判断して聴力レベルが 90dBHL未 満の耳に人工内耳埋込み術を行った。今回検討した
術側 90dBHL未満群の術後語音聴取能は, 全例に おいて良好な結果であったと言える。

2) 非術側 90dBHL 未満群（表 3 ）

全 5 例の術前語音聴取能は平均 $15.0 \%$, 術後語音 聴取能は平均 $39.6 \%$ であったが，予後良好な 2 例 (症例 $\mathrm{H} \cdot \mathrm{I}$ ：術後語音聴取能平均 $83 \%$ ) と予後不 良な 3 例（症例 $\mathrm{E} \cdot \mathrm{F} \cdot \mathrm{G}$ : 術後語音聴取能平均 10.7\%）に分かれた。

症例 $\mathrm{H}$ は良聴耳の急激な聴力低下に伴い語音聴取 能が低下したため，90dBHL 以上の悪聴耳に人工内 耳を挿入した。症例 I は両側慢性中耳炎により徐々 
$\mathrm{A}$

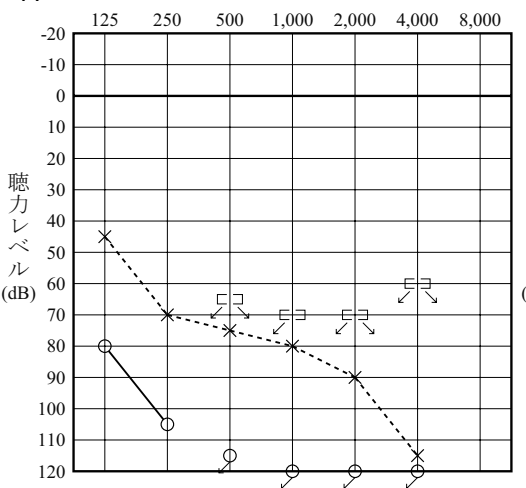

D

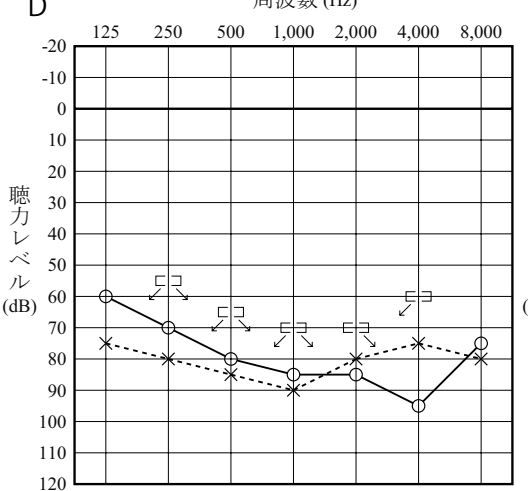

G

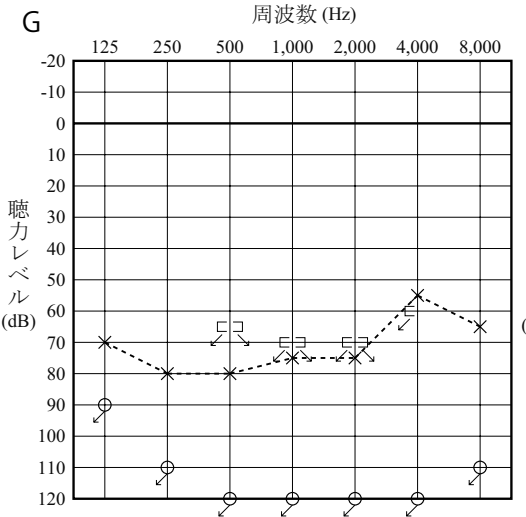

B

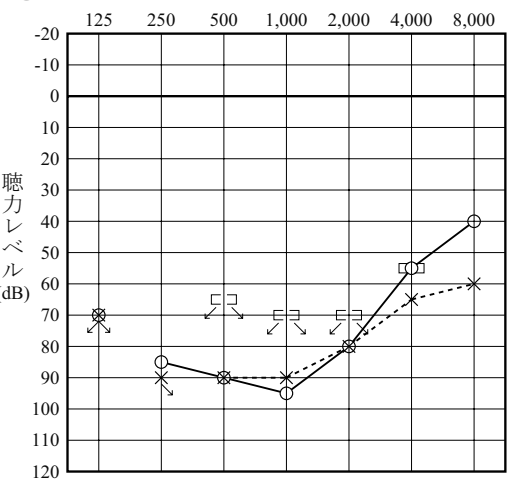

周波数 $(\mathrm{Hz})$

$\mathrm{E}$

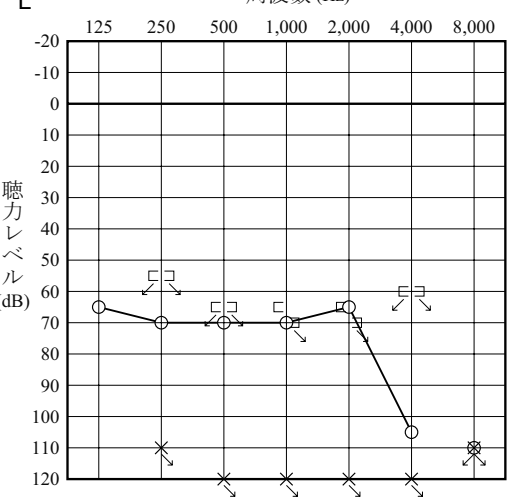

周波数 $(\mathrm{Hz})$

$\mathrm{H}$

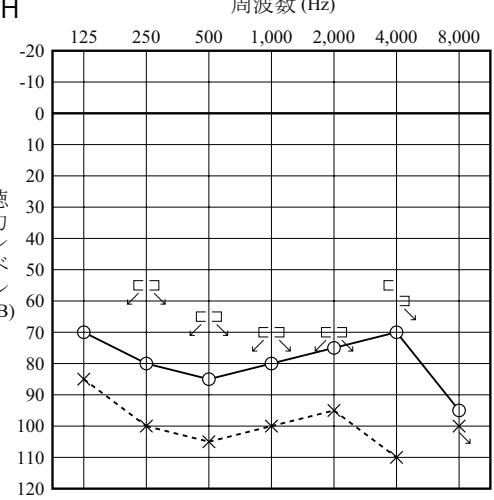

C

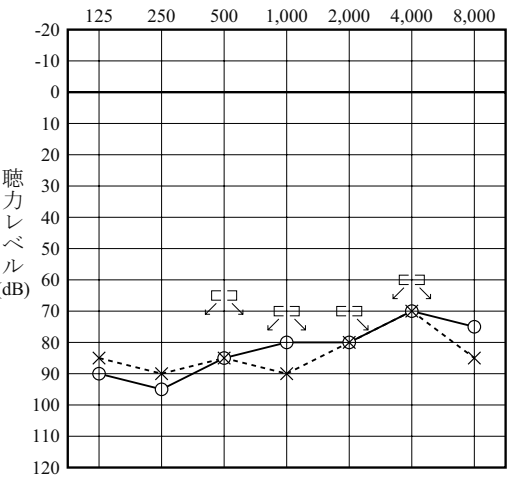

周波数 (Hz)

$\mathrm{F}$

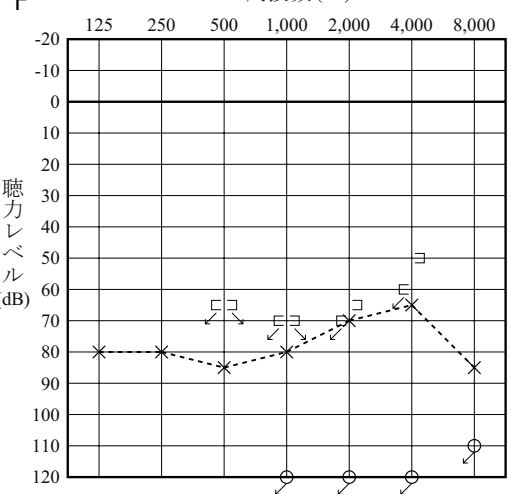

周波数 $(\mathrm{Hz})$

I

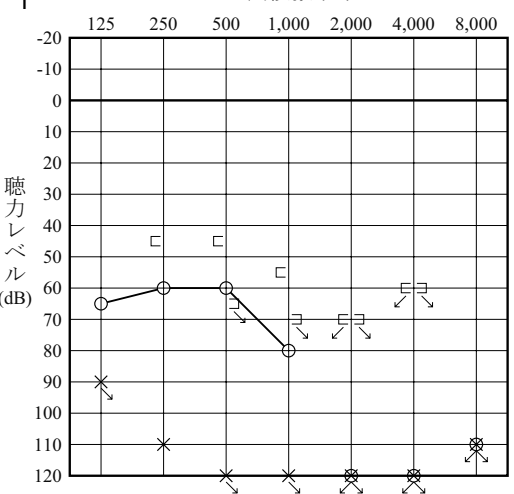

図 1 各症例の術前オージオグラム

に聴力の低下を認め, 語音聴取能が悪化して補聴器 の装用効果に乏しいと判断し，90dBHL 以上の悪聴 耳に人工内耳を挿入した。

予後不良であった 3 症例 $(\mathrm{E} \cdot \mathrm{F} \cdot \mathrm{G})$ は聴力レ ベルの変動は認められず, 補聴器装用下での語音聴 取能が極めて不良なため手術を行った。症例 $\mathrm{E}$ は䯣 膜炎に伴う難聴があり，ABR は両側 105dBHLで無 反応であった。術前の MRI 検查では螖牛骨化や内 耳道の狭窄・変性を認めず, Promontory Stimulation Test では左右差なく音検出閾值が得られたた
め，良聴耳を温存して悪聴耳に人工内耳埋込み術を 行った。成績不良の要因は髄膜炎による後迷路障 害7) と思われた。この症例では, 術後に対側への人 工内耳埋込みを勧めたが, 本人の希望が無いため行 っていない。症例 $\mathrm{F}$ も髄膜炎に伴う難聴があり, $\mathrm{ABR}$ は術側 105dBHLで無反応, 非術側は 105dBHLで $V$ 波を認めた。術前の MRI 検査では術側の螖牛骨 化を認めたが，非術側の骨化は認めず，内耳道の狭 窄・変性は認めなかった。Promontory Stimulation Testでは左右差なく音検出閾值が得られ，カロリ 
ックテストでは眼振最大緩徐相速度は術側 4 \% $\mathrm{sec}$ ・非術側眼振 $37^{\circ}$ / sec であった。髄膜炎罹患前 よりめまいの自覚があり, 患者希望で平衡機能残存 耳を温存した。全電極挿入可能であったが, 術後成 績は不良であり，髄膜炎による後迷路障害 ${ }^{7)}$ が原因 と考えられた。この症例も対側への人工内耳埋込み の希望が無く行っていない。症例 G は原因不明の難 聴があり，ABR は両側とも $105 \mathrm{dBHL}$ で無反応であ った。術前の MRI 検查では蝸牛・内耳道ともに正 常で, Promontory Stimulation Testは両側とも閾值 検出不能であった。失聴期間は術側 11 年・非術側 1 年と左右差を認めたが，患者希望により失聴後の期 間が短い良聴耳を温存した。本症例では長期失聴に 伴う蝸牛神経の変性等, 後迷路の障害 ${ }^{89}$ が成績不

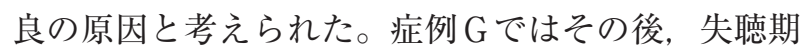
間の短い対側に人工内耳を挿入し, 術後語音聴取能 が $88 \%$ と良好な成績が得られた。

\section{考察}

良聴耳聴力レベルが 90dBHL未満であるにも関 わらず語音聴取能が不良な症例への人工内耳埋込み 術の術後成績について検討を行った。良聴耳聴力レ ベルが 90dBHL未満であった全 9 症例の術後語音 聴取能の平均は $58.4 \%$ であった。これは, 現行基準 に沿って当科で人工内耳埋达み術を行った両側 90 $\mathrm{dBHL}$ 以上の成人中途失聴者に求ける術後語音聴取 能平均66（ $\pm 22 ） \%(48$ 例：2005年-2015年）とほほ 同等の結果 (マン・ホイットニー検定, $\mathrm{p}=0.57$ ) であった。また, 術側聴力レベルが 90dBHL未満 であった症例は全例で良好な術後成績が得られた一 方で, 術側が 90dBHL 以上であった群は術後成績 にばらつきが認められた。

良聴耳の聴力レベルが 90dBHL未満であった症 例への人工内耳埋込み術の術後成績を検討している 過去の報告(5) に抢いては，いずれも両側とも 90 dBHL 以上であった症例の術後成績を上回る成績が 得られたとされている。一方で, 本研究では両側の 聴力レベルが 90dBHL 以上であった症例群の術後 成績を上回るまでには至らなかった。この要因とし ては, 症例数が少ないこと, またその中に（9症例 中 3 症例）髄膜炎に伴う難聴という特異的な症例が 含まれていたことが挙げられる。髄膜炎に伴う難聴
では後迷路障害を合併することが多いため, 人工内 耳の術後成績が不良な症例が存在することが知られ ている7”。本研究に抢いても髄膜炎に伴う難聴の 3 症例中 2 症例の術後成績は極めて不良であった。こ の特異的な 3 症例を除いて検討すると, 術後語音聴 取能の平均は $69 \%$ となる。これは現行の適応基準に 沿った症例の術後成績を上回っており，先行研究と 同様の結果となる。今後, 更なる症例の蓄積が必要 ではあるが，本邦においても聴力レベルが 90dBHL 未満であるが語音聴取能が不良な症例において, 失 聴期間が短く，かつ髄膜炎など高度の後迷路性障害 を来すような病態がない場合, 人工内耳埋込久術が 適応となることが，本研究においても明らかとなっ たと考えられる。

残存聴力のある症例に対する人工内耳埋込久術で は術側の選択が一つの問題となる。Gantz ら ${ }^{10)}$ は術 前の聴力レベルが術後成績に影響すると報告してい る。これを支持する報告として, 聴力レベルとらせ ん神経節神経細胞残存数が相関した ${ }^{11)}$ という報告を 認める。一方で, 術前の聴力レベルは術後成績に影 響しないという報告 ${ }^{5)}$ も認める。その裏付けとし て, 人工内耳埋达み患者に扔ける側頭骨標本の研究 において術後の語音聴取能と残存らせん神経節細胞 数に相関が認められなかったという報告 ${ }^{12)}$ がある。 実際に，残存聴力に左右差のある症例に対して，人 工内耳を良聴耳に挿入した場合と悪聴耳に挿入した 場合の術後成績を比較した過去の論文では，術後成 績に有意差は認めない ${ }^{13}$ か, むしろ悪聴耳に挿入し た方が術後成績は良好であった ${ }^{5514)}$ と報告されてい る。本研究では聴力レベルが 90dBHL未満の耳に 人工内耳を施行した群では全例良好な術後成績が得 られたのに対し, 聴力レベルが 90dBHL 以上の耳 に挿入した群では術後成績にばらつきがあり，前者 を支持する結果となった。但し，今回の症例の詳細 を検討すると, 術後成績不良であった 3 例のうち 2 例は䯣膜炎後の難聴という特異的な症例であり, 残 りの 1 例も術側の失聴期間が 11 年と長期であったと いう術後成績が不良 ${ }^{899}$ となる要因のある症例であ り, 術前の聴力レベルと術後成績の関係について結 論を出すには今後更なる症例の蓄積が必要であると 考える。

赤井らは, 聴力レベルが 90dBHL未満であって 
も語音聴取能不良例が多数存在することを報告して おり ${ }^{6}$ ，本邦でも聴力レベルが 90dBHL未満であっ ても語音聴取能が悪い症例が存在するのは明らかで ある。これら症例の中に，人工内耳を埋め込むこと によりよい音声コミュニケーションを実現し得る症 例が存在することが考えられる。本邦でも成人人工 内耳の適応基準においては純音聴力レベルだけでは なく語音聴取能を考慮した適応規準の設定を行うこ とが望ましいと考えている。

\section{まと め}

成人中途失聴のうち，良聴耳の聴力レベルが 4 分 法で 90dBHL未満であった 9 症例 9 耳について検 討した。術側耳の聴力レベルが 90dBHL未満であ った症例は 4 例で, 術側耳の聴力レベルが 90dBHL 以上で非術側耳の聴力レベルが 90dBHL未満であ った症例は 5 症例であった。全 9 症例の術後語音聴 取能の平均は，両側術前聴力レベルが 90dBHL 以 上であった症例の術後語音聴取能の平均とほぼ同等 であった。術側耳の聴力レベルが 90dBHL未満症 例の術後語音聴取能は全例, 両側術前聴力レベルが 90dBHL 以上であった症例の術後語音聴取能の平均 を上回ったのに対し，90dBHL 以上の耳に人工内耳 埋込み術を行った症例の成績にはばらつきを認め た。

本論文の要旨は第61回日本聴覚医学会（2016年10 月，盛岡市）においてロ演した。

本論文に関連し開示すべき利益相反はありませ ん。

\section{Consideration of cochlear implantation for patients with a hearing level of less than 90} dB.

Masako Katsushika ${ }^{1)}$, Erika Ogata ${ }^{2)}$, Yusuke Akamatsu ${ }^{2)}$, Akinori Kashio ${ }^{2)}$, Shotaro Karino ${ }^{2)}$, Shinichi Iwasaki ${ }^{2)}$, Tatsuya Yamasoba ${ }^{2)}$

${ }^{1)}$ Department of Otolaryngology and Head and Neck Surgery, NTT Medical Center Tokyo

${ }^{2}$ Department of Otolaryngology and Head and
Neck Surgery, The University of Tokyo

The current criteria for adult cochlear implantation in Japan are based on the hearing level. However, in other countries, such as the United States, they are based on word recognition scores. In Japan, there are individuals who have difficulty in communication, even when their hearing level is less than 90dBHL. In the current study, we evaluated the results of speech perception following cochlear implantation in nine subjects who had had poor word recognition, but a hearing level of less than 90dBHL in the better hearing ear before cochlear implantation. The average postoperative word recognition scores of these nine subjects was almost equal to the average postoperative word recognition scores of other adult subjects with a bilateral hearing level of more than 90dBHL. The postoperative speech recognition scores of the four subjects who received the cochlear implant in the ear with a hearing level of less than 90dBHL were generally good. However, there was variability in the results of the five subjects who received the cochlear implant in the ear with a hearing level of greater than 90dBHL. These results indicate that Japanese individuals with poor word recognition scores and a hearing level of less than 90dBHL are candidates for cochlear implantation.

\section{文献}

1 ）守本倫子：小児人工内耳の新適応規準. Otology Japan 25 : 141-143, 2015

2）神田幸彦：小児人工内耳の低年齢化と両耳装 用. ENTONI 181 : 28-35, 2015

3 ) Vickers D, De Raeve L, Graham J : International survey of cochlear implant candidacy. Cochlear Implants International 17 : 36-41, 2016

4 ) Francis HW, Yeagle JD, Brightwell T, et al: Central effects of residual hearing: implications for choice of ear for cochlear implantation. Laryngoscope 114 : 1747-1752, 2004

5 ) Francis HW, Yeagle JD, Bowditch S, et al : 
Cochlear implant outcome is not influenced by the choice of ear. Ear and Hearing 26: 7S-16S, 2005

6 ）赤井貞康，小寺一興，矢吹今日子，他：感音 難聴における聴力䦨值と語音明瞭度との関係.

Audiology Japan 33 : 210-214, 1990

7 ）池谷 淳, 河野 淳, 萩原 晃, 他：成人期 に人工内耳植込々術を施行した䯣膜炎後難聴症 例の検討。耳鼻咽喉科展望 58：75-83，2015

8 ）森 尚彫, 伊藤壽一, 平海晴一, 他: 成人人 工内耳長期装用例における装用域値と後迷路機 能. Audiology Japan 55 : 190-197, 2012

9）内藤 明, 北野庸子, 高橋正紘, 他：人工内 耳装用者に扮ける聴覚順応と可塑性一音響心理 学的検討一. Audiology Japan 43: 210-214, 2000

10) Gantz BJ, Woodworth GG, Knutson JF, et al : Multivariate predictors of audiological success with multichannel cochlear implants. Annals of Otology, Rhinology and Laryngology 102 : 909916, 1993

11) Incesulu A, Nadol JB : Correlation of acoustic threshold measures and spiral ganglion cell survival in severe to profound sensorineural hearing loss. Annals of Otology, Rhinology and Laryngology 107 : 906-911, 1998

12) Linthicum Jr. FH, Fayad J, Otto SR, et al :
Cochlear implant histopathology. The American Journal of Otology 12 : 245-311, 1991

13) Lassaletta L, Calvino M, Sanchez-Cuadrado I, et al: Which ear should we choose for cochlear implantation in the elderly: The poorer or the better? Audiometric outcomes, quality of sound, quality-of-life results. Acta Oto-Laryngologica 135 : 1268-1276, 2015

14) Franko-Tobin E, Camilon PR, Camposeo E, et al: Outcomes of cochlear implantation in adults with asymmetric hearing loss. Otology and Neurotology 36 : 409-415, 2015

（2017年2月1日受稿 2017年5月2日受理）

別冊請求先 : $\bar{\top} 141-8625$

東京都品川区東五反田 5-9-22

NTT 東日本関東病院耳鼻咽喉科・頭 頸部外科

勝然昌子

Masako Katsushika

Department of Otolaryngology and Head and Neck Surgery, NTT Medical Center Tokyo

5-9-22, Higashi-Gotanda, Shinagawaku, Tokyo 141-8625, Japan 